J Am Chem Soc. 2017 August 02; 139(30): 10196-10199. doi:10.1021/jacs.7b05196.

\title{
Enantioselective Total Synthesis of Nigelladine A via Late-Stage C-H Oxidation Enabled by an Engineered P450 Enzyme
}

\author{
Steven A. Loskot, David K. Romney, Frances H. Arnold ${ }^{\star}$, and Brian M. Stoltz \\ Division of Chemistry and Chemical Engineering, California Institute of Technology, Pasadena, \\ California 91125
}

\begin{abstract}
An enantioselective total synthesis of the norditerpenoid alkaloid nigelladine A is described. Strategically, the synthesis relies on a late stage $\mathrm{C}-\mathrm{H}$ oxidation of an advanced intermediate. While traditional chemical methods failed to deliver the desired outcome, an engineered cytochrome $\mathrm{P} 450$ enzyme was employed to effect a chemo- and regioselective allylic $\mathrm{C}-\mathrm{H}$ oxidation in the presence of four oxidizable positions. The enzyme variant was readily identified from a focused library of three enzymes, allowing for completion of the synthesis without the need for extensive screening.
\end{abstract}

\section{Graphical abstract}

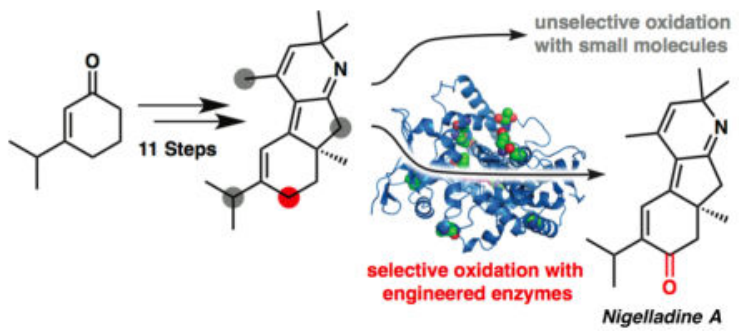

The field of organic synthetic chemistry has benefited greatly from the many recent advances in selective $\mathrm{C}-\mathrm{H}$ functionalization. ${ }^{1}$ Indeed, chemical oxidations of $\mathrm{C}-\mathrm{H}$ bonds are some of the most important transformations in synthetic chemistry because they allow for direct access to oxidized intermediates, without the need for synthetic handles or functional group interconversions. Despite recent advances, there remain significant limitations regarding the regioselectivity of non-directed $\mathrm{C}-\mathrm{H}$ oxidation reactions. We envisioned that the recently isolated norditerpenoid alkaloids nigelladines A-C (1-3) and pyrroloquinoline alkaloid nigellaquinomine (4) (Figure 1) ${ }^{2}$ would present a challenging test bed to evaluate the viability of late-stage $\mathrm{C}-\mathrm{H}$ oxidation methods.

With respect to nigelladine $\mathrm{A}$, we believed that late-stage installation of the $\mathrm{C} 7$ ketone would offer significant flexibility in how we chose to construct the highly conjugated core of

Corresponding Authors: B.M.S.: stoltz@ caltech.edu, F.H.A.: frances@ cheme.caltech.edu.

Supporting Information. Experimental procedures and characterization data as Supporting Information is available free of charge on the ACS Publications website at DOI: 10.1021/jacs.5b00000. 
alkaloid 1. However, despite the abundance of chemical allylic oxidation conditions, there are relatively few examples of selective oxidation at a $2^{\circ}$ carbon (e.g., C7) in the presence of a non-bridging $3^{\circ}$ carbon (e.g., C10), since oxidation generally occurs at the position where hydrogen abstraction is most favorable. ${ }^{4}$ On the other hand, enzymes are well known to catalyze oxidation reactions with regioselectivity that defies conventional trends of chemical reactivity. Despite this, enzymatic methods are often overlooked in total synthesis efforts due to a typically narrow substrate scope deriving from their exceptional specificity. Fortunately, recent progress in the field of directed evolution has greatly increased the viability of biocatalysis in total synthesis by increasing the reactivity and selectivity of enzymes for nonnative transformations. ${ }^{5,6}$ Biocatalytic $\mathrm{C}-\mathrm{H}$ oxidations with engineered enzymes thus present an alternative approach that can circumvent the limitations of traditional chemical oxidations. Nonetheless, even though there have been examples of the use of engineered enzymes for the functionalization of complex molecules, ${ }^{7}$ their application in total syntheses is still very limited. Herein we report the first enantioselective total synthesis of tricyclic alkaloid 1, enabled by the selective late-stage allylic oxidation of unsaturated imine $\mathbf{5}$ via an engineered P450 enzyme.

Retrosynthetically, we surmised that selective late-stage allylic oxidation of $\mathbf{5}$ at $\mathrm{C7}$ would be essential to the synthesis of enone $\mathbf{1}$. Imine $\mathbf{5}$ could be generated by the cross-coupling of vinyl boronic ester $\mathbf{6}$ and bromide dienone 7 . Vinyl bromide $\mathbf{7}$ was envisioned to arise via annulation of enone $\mathbf{8}$, with the quaternary stereocenter constructed by an asymmetric allylic alkylation reaction from $\beta$-ketoester $9 .{ }^{8}$ With this retrosynthetic analysis, we recognized that the strategically planned $\mathrm{C}-\mathrm{H}$ oxidation would be particularly challenging due to issues of site selectivity. Imine $\mathbf{5}$ contains three different allylic carbon centers that could be susceptible to oxidation, a $1^{\circ}, 2^{\circ}$, and $3^{\circ}$, in addition to a relatively acidic a-carbon adjacent to the imine. Together, the natural product combined with our strategic analysis unveiled a challenging problem for selective $\mathrm{C}-\mathrm{H}$ functionalization that would need to be addressed in a successful synthesis.

In the forward direction, known enone $\mathbf{1 0}$ can be synthesized in excellent yield through a Stork-Danheiser transposition from 1,3-cyclohexanedione. ${ }^{9,10}$ Unfortunately, attempts to directly acylate the a-carbon of $\mathbf{1 0}$ resulted in low yields due to competing self-aldol additions. To avoid these issues, we chose to increase the reactivity and steric environment of the enolate by synthesizing the 1,1-dimethyl hydrazone $11 .{ }^{11}$ Hydrazone 11 was readily acylated then hydrolyzed, and the resulting $\beta$-ketoester was subsequently methylated, providing our desired asymmetric allylic alkylation substrate (9) in good yield (73\% over 3 steps, Scheme 1). With $\beta$-ketoester 9 in hand, we evaluated a variety of reaction parameters for the key quaternary stereocenter-forming asymmetric allylic alkylation and determined that the use of $\left(\mathrm{CF}_{3}\right)_{3}-t$-Bu-PHOX (L1)12 in 2:1 hexanes-toluene with $\mathrm{Pd}_{2}\left(\mathrm{dba}_{3}\right.$ was optimal, generating desired enone $\mathbf{8}$ in $96 \%$ yield and $87 \%$ ee. Standard Tsuji-Wacker oxidation of enone 8 using $\mathrm{PdCl}_{2}$ and $\mathrm{CuCl}$ under an atmosphere of oxygen generated the desired ketone, ${ }^{13}$ which subsequently underwent an aldol condensation to provide dienone $\mathbf{1 2}$ in good yield (76\% yield over 2 steps). ${ }^{14}$ Enone 12 was then selectively monobrominated to form vinyl bromide 7 in $83 \%$ yield on gram scale. ${ }^{15}$ The cross coupling of $6^{16}$ and 7 was next evaluated for optimal reaction conditions. Ultimately, we found that 
Buchwald's $2^{\text {nd }}$ generation precatalyst with XPhos (XPhos Pd G2) ${ }^{17}$ allowed for the union of $\mathbf{6}$ and $\mathbf{7}$ in $88 \%$ yield using only a slight excess (1.1 equiv) of $\mathbf{6}$. Furthermore, triene $\mathbf{1 3}$ provided crystals suitable for $\mathrm{X}$-ray diffraction and allowed us to ascertain absolute stereochemistry. ${ }^{18}$

With triene $\mathbf{1 3}$ in hand, we turned our attention to the synthesis of the heterocyclic portion of the alkaloid and the final stages of the synthesis. Toward that end, triene $\mathbf{1 3}$ was treated with trifluoroacetic acid (TFA) in $\mathrm{CH}_{2} \mathrm{Cl}_{2}$ to deprotect the amine, which spontaneously cyclized to form the requisite imine upon quenching with aqueous sodium bicarbonate (Scheme 2). Fortuitously, upon removal of the aqueous layer, treatment with silica gel promoted isomerization of the exocyclic olefin into the ring, which, after purification, afforded the TFA salt of $\mathbf{5}$ in $75 \%$ yield (25\% over 10 steps from enone 10). ${ }^{19}$

With only an allylic oxidation separating tricycle 5 from nigelladine A (1), we initiated a broad exploration of oxidation methods for installing an oxidation handle at the desired $\mathrm{C} 7$ position. Unfortunately, the required site-selective $\mathrm{C}-\mathrm{H}$ oxidation of $\mathbf{5}$ or the intermediate enone 13 proved intractable for traditional synthetic methods (Table 1). While numerous conditions were probed on both substrates, ${ }^{20,21}$ only a limited few effected oxidation at the desired position. These reactions also exhibited poor selectivity, generating an inseparable mixture of mono-oxidation products, along with over-oxidized byproducts that constituted the majority of the product mixture. We thus turned our attention to enzymes as a potential means to achieve the desired oxidation.

The cytochrome $\mathrm{P} 450$ enzyme from Bacillus megaterium ( $\mathrm{P} 450_{\mathrm{BM} 3}$ ) is a workhorse of protein engineering studies because it is soluble and self-contained, exhibits one of the fastest reaction rates of any $\mathrm{P} 450$-catalyzed hydroxylation $\left(17,000 \mathrm{~min}^{-1}\right.$ for arachidonic acid) ${ }^{5 \mathrm{a}}$ and possesses good stability $\left(t_{1 / 2}=68 \mathrm{~min}\right.$ at $\left.50{ }^{\circ} \mathrm{C}\right) .{ }^{22}$ Since the substrate scope of the wild-type protein is mostly limited to long-chain fatty acids, many engineering efforts have focused on expanding the substrate scope of $\mathrm{P}_{450} 0_{\mathrm{BM} 3}$ to accept larger and more complex substrates. To this end, various approaches have been applied to develop biocatalysts derived from $\mathrm{P} 450_{\mathrm{BM} 3}$ that perform regioselective $\mathrm{C}-\mathrm{H}$ oxygenation of complex molecules for which the wild-type enzyme exhibits minimal activity. ${ }^{6 c, 23}$ However, these approaches involved extensive screening endeavors, often requiring high-throughput screening and limiting them to substrates that were readily available.

For biocatalysis to be a viable strategy for the late-stage of a total synthesis, it is desirable to identify a synthetically useful catalyst with minimal screening. Thus, we elected to screen a focused library of variants that had been previously engineered to accept large substrates, ${ }^{23}$ but had otherwise never encountered substrate $\mathbf{5}$. To compare the catalysts, we chose to allow the reactions to proceed to only low conversion and compare the ratio of desired to undesired oxidation products (Table 2). Encouragingly, wild-type $\mathrm{P}_{450} \mathrm{BM}_{\mathrm{BM}}$ exhibited some selectivity for $\mathrm{C}$, although oxidation of the isopropyl C-H bond was favored 1.2:1 (Table 2, entry 1). We then probed a small selection of engineered variants that all derive from the same parent (12 mutations from $\mathrm{P} 450_{\mathrm{BM} 3}$ ). These enzymes were previously evolved for regioselective oxidation of methoxymethyl-protected glycosides, but are distinct in that different combinations of active-site residues have been mutated to alanine. The variant $\mathbf{2 A 1}$, 
in which leucine residues 75,181 , and 437 are mutated to alanine, exhibited a worse selectivity compared to wild-type, favoring the isopropyl oxidation product, as well as an unidentified oxidation product (Table 2, entry 2). The two other variants, however, exhibited a reversal in selectivity, favoring oxidation at the desired position in excess of 2:1 (Table 2, entries 3-4). The best variant proved to be $\mathbf{8 C 7}$, which is identical to $\mathbf{2 A 1}$, but lacks the L437A mutation. This variant favors oxidation at the desired position in a 2.8:1 ratio (Table 2, entry 4).

Since enzyme active sites are well known to bind substrate enantiomers differently, we wished to test if the stereochemistry of $\mathbf{5}$ would affect the activity or selectivity of $\mathbf{8 C 7}$. Using the Pd-catalyzed alkylation, we obtained both enantiomers of $\mathbf{5}$, which were then enriched to enantiopurity by chiral preparative HPLC. Each enantiomer was then subjected to oxidation by catalyst $\mathbf{8 C} 7$. Interestingly, at both short $(15 \mathrm{~min})$ and long $(12 \mathrm{~h})$ reaction times, the enantiomers gave nearly identical results, although the $R$ enantiomer exhibited a slightly higher initial rate by a factor of 1.3 .

Having achieved the desired regioselectivity, we then needed to improve the yield. Furthermore, we wished to supplant the stoichiometric use of NADPH, which is required if oxygen is used as the terminal oxidant. Fortunately, we could use NADPH in catalytic amounts by regenerating it in situ with an alcohol dehydrogenase (ADH) and isopropanol as the terminal reductant. ${ }^{24}$ With these new conditions, we conducted the oxidation on a 160 $\mathrm{mg}$ scale, followed by subjecting the crude product mixture to oxidation with Dess-Martin periodinane, thus affording the natural product in $21 \%$ yield over both steps (43\% yield based on recovered $\mathbf{5}$, Scheme 3 ). The recovered starting material (5) was competent in the same two-step procedure with no loss in efficiency (26\% yield) ${ }^{25}$ Under these conditions, we observed up to 1700 turnovers to the $\mathrm{C} 7$ mono-oxygenation product.

In summary, we have completed the first total synthesis of nigelladine A in an expedient 12 steps and 5\% overall yield (11\% yield based on recovered $\mathbf{5}$ ). The asymmetric allylic alkylation allowed for the construction of the quaternary center in high yield and enantioselectivity. Expedient identification of engineered enzymes allowed for a siteselective $2^{\circ}$ allylic oxidation without the need for extensive generational screening or reaction optimization. These results demonstrate that enzymatic transformations are capable of defying standard chemical limitations and should be included in the repertoire of reactions that are traditionally considered for the late stages of total syntheses.

\title{
Supplementary Material
}

Refer to Web version on PubMed Central for supplementary material.

\section{Acknowledgments}

\author{
Funding Sources \\ No competing financial interests have been declared. \\ This work was supported by the NSF under the CCI Center for Selective C-H Functionalization (CHE-1205646). \\ D.K.R. was supported by a Ruth Kirschstein NIH Postdoctoral Fellowship (F32GM117635). Additional financial \\ support was provided by Caltech and Novartis. We thank Dr. Scott Virgil (CIT) and the Caltech 3CS for access to
}


analytical equipment. The authors gratefully acknowledge Larry Henling and Dr. Michael Takase (CIT) for X-ray crystallographic structural determination, Dr. Mona Shahgholi and Naseem Torian (CIT) for mass spectrometry assistance, and Dr. David VanderVelde (CIT) for NMR experimental assistance and helpful discussions. The authors also acknowledge Dr. Sabine Brinkmann-Chen and Dr. Stephan Hammer (CIT) for helpful discussions regarding the enzymatic oxidation system.

\section{References}

1. For recent reviews on direct C-H functionalization see: Lyons TW, Sanford MS. Chem Rev. 2010; 110:1147-1169. [PubMed: 20078038] Wencel-Delord J, Dröge T. Chem Soc Rev. 2011; 40:47404761. [PubMed: 21666903] Engle KM, Mei TS, Wasa M, Yu JQ. Acc Chem Res. 2012; 45:788802. [PubMed: 22166158] Wendlandt AE, Suess AM, Stahl SS. Angew Chem, Int Ed Engl. 2011; 50:11062-11087. [PubMed: 22034061] Gutekunst WR, Baran PS. Chem Soc Rev. 2011; 40:19761991. [PubMed: 21298176] Yamaguchi J, Yamaguchi AD, Itami K. Angew Chem Int Ed Engl. 2012; 51:8960-9009. [PubMed: 22887739] Davies HML, Manning JR. Nature. 2008; 451:417-424. [PubMed: 18216847]

2. a) Chen QB, Xin XL, Yang Y, Lee SS, Aisa HA. J Nat Prod. 2014; 77:807-812. [PubMed: 24593120] b) Zhang S, Zhang ZY. Drug Discovery Today. 2007:373-381. [PubMed: 17467573]

3. Nakamura A, Nakada M. Synthesis. 2013; 45:1421-1451.

4. Weidmann V, Maison W. Synthesis. 2013; 45:2201-2221.

5. For reviews of biocatalysis and directed evolution see: Arnold FH. Acc Chem Res. 1998; 31:125131.Reetz MT. Angew Chem, Int Ed Engl. 2001; 40:284-310. [PubMed: 11180317] Turner NJ. Nat Chem Biol. 2009; 5:567-573. [PubMed: 19620998] Wohlgemuth R. Curr Opin Biotechnol. 2010; 21(6):713. [PubMed: 21030244] Reetz MT. J Am Chem Soc. 2013; 135:12480-12496. [PubMed: 23930719] Nestl BM, Hammer SC, Nebel BA, Hauer B. Angew Chem, Int Ed Engl. 2014; 53(12): 3070. [PubMed: 24520044] Denard CA, Ren H, Zhao H. Curr Opin Chem Biol. 2015; 25:55-64. [PubMed: 25579451]

6. a) Jung ST, Lauchli R, Arnold FH. Curr Opin Biotechnol. 2011; 22(6):809-817. [PubMed: 21411308] b) Whitehouse CJ, Bell SG, Wong LL. Chem Soc Rev. 2012; 41:1218-1260. [PubMed: 22008827] c) Janocha S, Schmitz D, Bernhardt R. Adv Biochem Eng/Biotechnol. 2015; 148:215250.d) Roiban GD, Reetz MT. Chem Commun. 2015; 51:2208-2224.

7. a) Hoffmeister D, Yang J, Liu L, Thorson JS. Proc Natl Acad Sci U S A. 2003; 100:13184-13189. [PubMed: 14612558] b) Whitehouse CJC, Bell SG, Tufton HG, Kenny RJP, Ogilvie LCI, Wong LL. Chem Commun. 2008:966-968.c) Zhang K, Shafer BM, Demars MD II, Stern HA, Fasan R. J Am Chem Soc. 2012; 134:18695-18704. [PubMed: 23121379] d) Abreu M, Alvaro-Benito M, SanzAparicio J, Plou FJ, Fernandez-Lobato M, Alcalde M. Adv Synth Catal. 2013; 355:1698-1702.

8. Behenna DC, Mohr JT, Sherden NH, Marinescu SC, Harned AM, Tani K, Seto M, Ma S, Novak Z, Krout MR, McFadden RM, Roizen JL, Enquist JA Jr, White DE, Levine SR, Petrova KV, Iwashita A, Virgil SC, Stoltz BM. Chem - Eur J. 2011; 17:14199. [PubMed: 22083969]

9. Stork G, Danheiser RL. J Org Chem. 1973; 38:1775-1776.

10. Dimitrov V, Kostova K, Genov M. Tetrahedron Lett. 1996; 37:6787-6790.

11. Corey EJ, Enders D. Tetrahedron Lett. 1976; 17:3-6.

12. McDougal NT, Streuff J, Mukherjee H, Virgil SC, Stoltz BM. Tetrahedron Lett. 2010; 51:55505554. [PubMed: 21076623]

13. Mehta G, Shinde HM. J Org Chem. 2012; 77:8056-8070. [PubMed: 22897237]

14. Day JJ, McFadden RM, Virgil SC, Kolding H, Alleva JL, Stoltz BM. Angew Chem, Int Ed Engl. 2011; 50:6814-6818. [PubMed: 21671325]

15. Zhu J, Germain AR, Porco JA Jr. Angew Chem, Int Ed Engl. 2004; 43:1239-1243. [PubMed: 14991787]

16. Vinyl boronic ester $\mathbf{6}$ can be readily prepared in three steps from commercially available isobutyric acid via propargylation, Curtius rearrangement, and Markovnikov hydroboration (see Supporting Information).

17. Bruno NC, Tudge MT, Buchwald SL. Chem Sci. 2013; 4:916-920. [PubMed: 23667737]

J Am Chem Soc. Author manuscript; available in PMC 2017 November 09. 


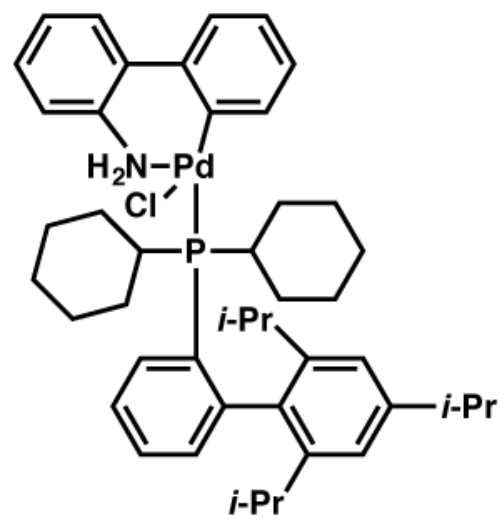

XPhos Pd G2

18. Crystals grown for X-ray crystallography were synthesized in the enantiomeric series using (S)$\mathrm{CF}_{3}-\mathrm{BBu}-\mathrm{PHOX}$ for the asymmetric allylic alkylation of $\mathbf{9}$.

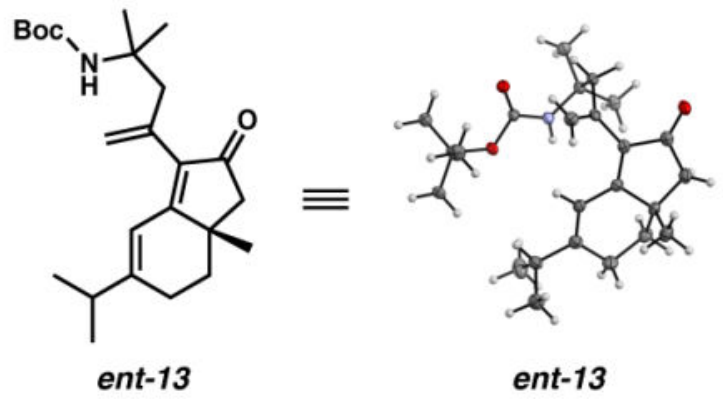

19. The TFA salt of $\mathbf{5}$ can be deprotonated to the free imine by an aqueous wash with $10 \%$ potassium carbonate.

20. See SI for full list of conditions and results.

21. a) Salmond WG, Barta MA, Havens JL. J Org Chem. 1978; 43:2057-2059.b) Chen MS, Prabagaran N, Labenz NA, White CM. J Am Chem Soc. 2005; 127:6970-6971. [PubMed: 15884938] c) Yu JQ, Corey EJ. Org Lett. 2002; 4:2727-2730. [PubMed: 12153220] d) Xing X, O'Connor NR, Stoltz BM. Angew Chem, Int Ed Engl. 2015; 54:11186-11190. [PubMed: 26234251] e) Sparling BA, Moebius DC, Shair MD. J Am Chem Soc. 2013; 135:644-647. [PubMed: 23270309] f) Schmuff NR, Trost BM. J Org Chem. 1983; 48:1404-1412.g) Zhao Y, Yeung YY. Org Lett. 2010; 12:2128-2131. [PubMed: 20387842] h) Wang Y, Kuang Y, Wang Y. Chem Commun. 2015; 51:5852-5855.i) Wilde NC, Isomura M, Mendoza A, Baran PS. J Am Chem Soc. 2014; 136:4909-4912. [PubMed: 24625050] j) Young WB, Masters JJ, Danishefsky S. J Am Chem Soc. 1995; 117:5228-5234.k) Jasiczak J. J Chem Soc, Perkin Trans 1. 1988:26872692.1) Horn EJ, Rosen BR, Chen Y, Tang J, Chen K, Eastgate MD, Baran PS. Nature. 2016; 533:77-81. [PubMed: 27096371] m) Allen JG, Danishefsky SJ. J Am Chem Soc. 2001; 123:351352. [PubMed: 11456530] n) Quinn RK, Könst ZA, Michalak SE, Schmidt Y, Szklarski AR, Flores AR, Nam S, Horne DA, Vanderwal CD, Alexanian E. J Am Chem Soc. 2016; 138:696-702. [PubMed: 26694767]

22. Lewis JC, Mantovani SM, Fu Y, Snow CD, Komor RS, Wong C-H, Arnold FH. ChemBioChem. 2010; 11:2502-2505. [PubMed: 21108271]

23. (a) Rentmeister A, Arnold FH, Fasan R. Nat Chem Biol. 2009; 5:26-28. [PubMed: 19011638] (b) Lewis JC, Bastian S, Bennett CS, Fu Y, Mitsuda Y, Chen MM, Greenberg WA, Wong CH, Arnold FH. Proc Natl Acad Sci U S A. 2009; 106:16550-16555. [PubMed: 19805336] (c) Kille S, Zilly FE, Acevedo JP, Reetz MT. Nat Chem. 2011; 3:738-743. [PubMed: 21860465]

24. Wolberg M, Hummel W, Wandrey C, Müller M. Angew Chem, Int Ed Engl. 2000; 39:4306-4308. 
25. The TFA salt of $\mathbf{5}$ was used to avoid deleterious aerobic oxidation of $\mathbf{5}$. Both the TFA salt and the free base of $\mathbf{5}$ were competent substrates and reacted identically for the enzymatic oxidation. 


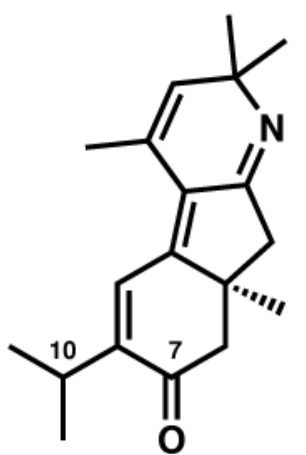

Nigelladine

A (1)

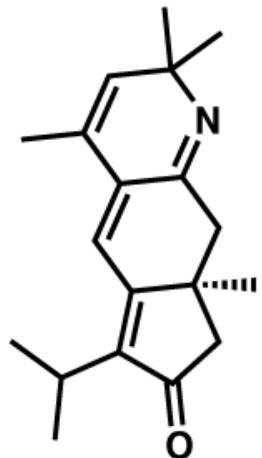

Nigelladine $B$ (2)

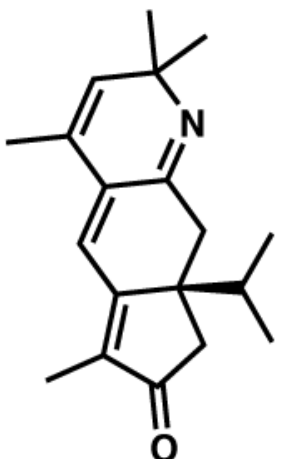

Nigelladine C (3)

Figure 1.

Structures of nigelladines $\mathrm{A}-\mathrm{C}$ and nigel-laquinomine. 
<smiles>CC1=CC(C)(C)N=C2C[C@@]3(C)CC(=O)C(C(C)C)=CC3=C12</smiles>

Nigelladine A (1)

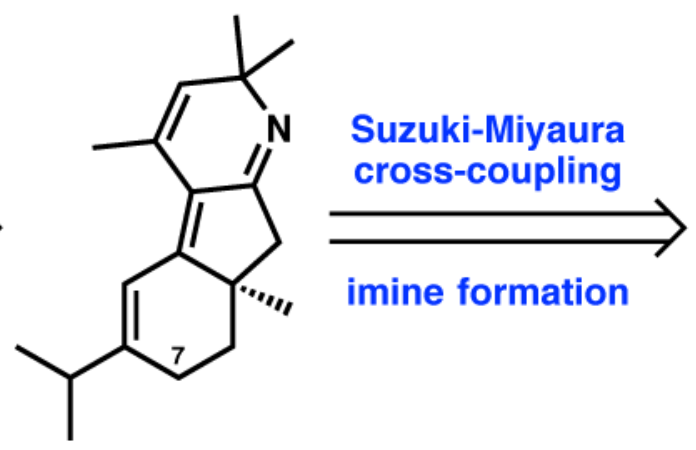

5<smiles>C=CC[C@]1(C)CCC(C(C)C)=CC1=O</smiles><smiles>C=CCOC(=O)C1(C)CCC(C(C)C)=CC1=O</smiles>

Figure 2.

Retrosynthetic analysis of nigelladine A (1). 
<smiles>CC(C)C1=CC(=O)CCC1</smiles>

10

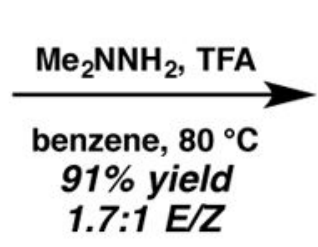

1.7:1 E/Z<smiles>CC(C)C1=C/C(=N/N(C)C)CCC1</smiles>

11<smiles>C=CCOC(=O)Cl</smiles>

1. LDA, THF, $-78^{\circ} \mathrm{C}$

2. $1 \mathrm{M} \mathrm{HCl}, \mathrm{THF}, 50^{\circ} \mathrm{C}$

3. Mel, NaH, DMF, $0^{\circ} \mathrm{C}$ $73 \%$ yield over 3 steps<smiles>C=CCOC(=O)C1(C(=O)OCC=C)CCC(C(C)C)=CC1=O</smiles><smiles>CC(C)C1=CC2=C(Br)C(=O)C[C@]2(C)CC1</smiles>

6 (1.1 equiv)

XPhos Pd G2 (3 mol \%) $0.5 \mathrm{M} \mathrm{K}_{3} \mathrm{PO}_{4}$

THF, $50{ }^{\circ} \mathrm{C}$

$88 \%$ yield<smiles>C=C(CC(C)(C)NC(=O)OC(C)(C)C)C1=C2C=C(C(C)C)CC[C@]2(C)CC1=O</smiles><smiles>CC(C)(C)[C@H]1COC(c2cc(C(F)(F)F)ccc2Pc2ccccc2)=N1</smiles>

Scheme 1.

Synthesis of dienone $\mathbf{1 3}$ 


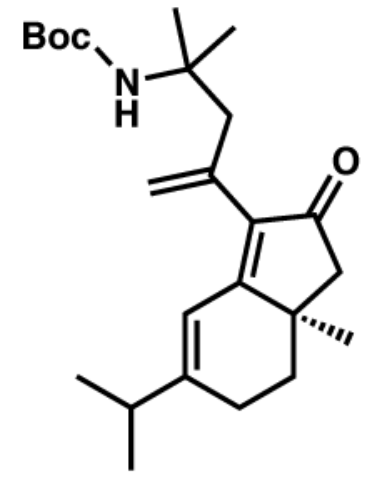

13<smiles>CC1CCC1[I+]</smiles>

TFA, DCM, $23^{\circ} \mathrm{C}$;

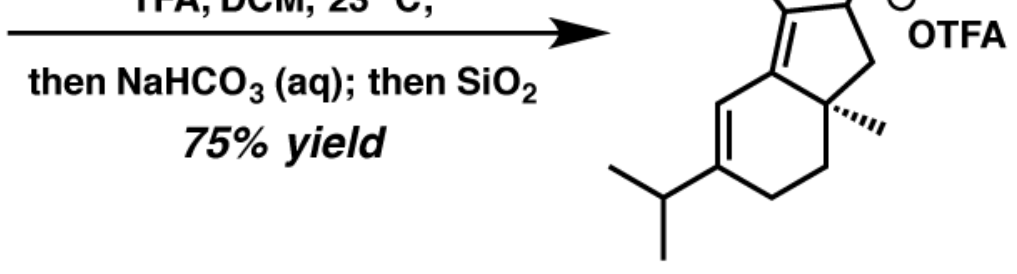

5.TFA (25\% yield from 10 , over 10 steps)

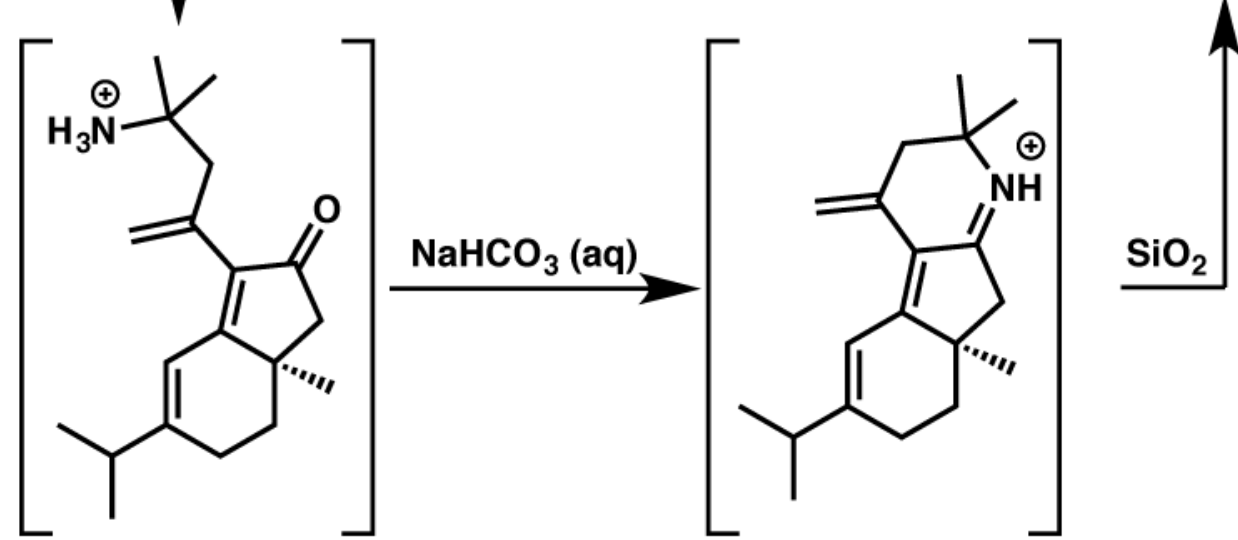

Scheme 2.

Condensation of imine 5 


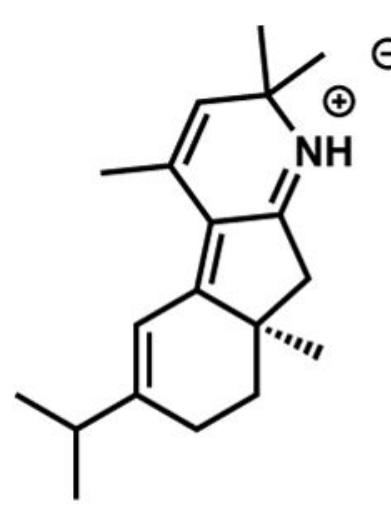

$5 \cdot$ TFA
OTFA 1. P450 $8 \mathrm{C} 7$ (0.02 to $0.04 \mathrm{~mol} \%)$ NADP (10 mol \%), $i$-PrOH, ADH $2.5 \%$ DMSO in KPi buffer (pH 8) $23^{\circ} \mathrm{C}, 12 \mathrm{~h}$

2. DMP, $\mathrm{CH}_{2} \mathrm{Cl}_{2}, 0^{\circ} \mathrm{C}, 4 \mathrm{~h}$

$21 \%$ yield over 2 steps $43 \%$ yield based on recovered 5

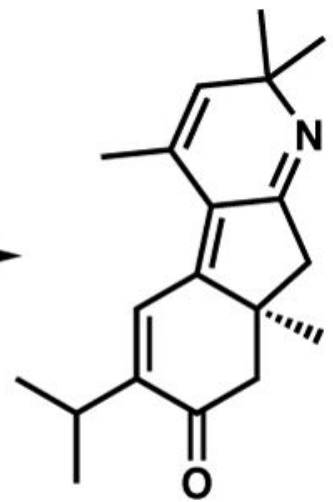

1

Scheme 3.

Completion of the synthesis of nigelladine $\mathrm{A}^{\mathrm{a}}$

aADH, alcohol dehydrogenase; KPi, potassium phosphate; DMP, Dess-Martin periodinane. 


\section{롤 \\ 골}

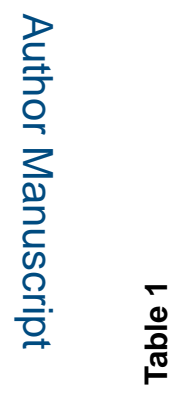

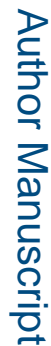

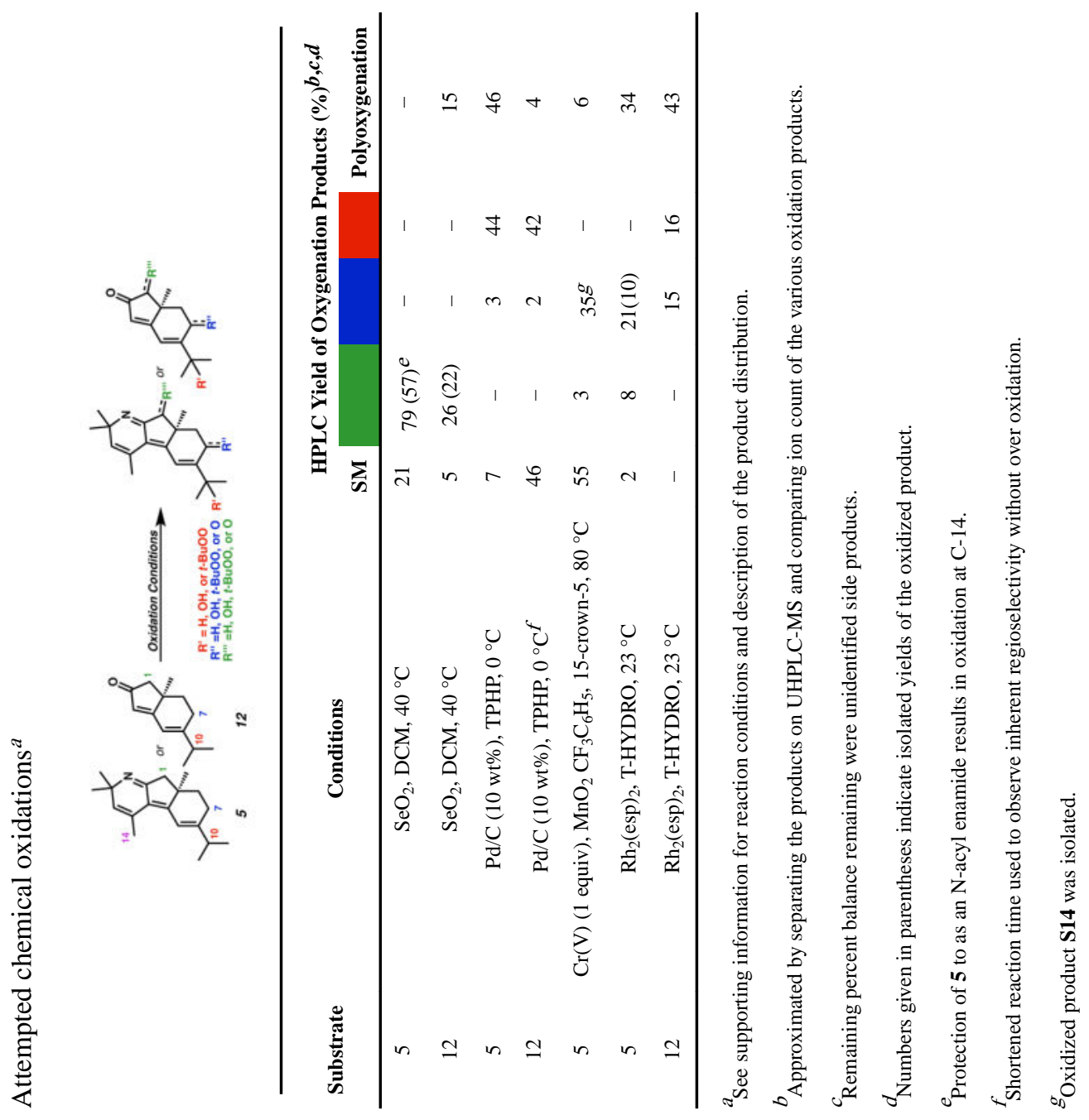

J Am Chem Soc. Author manuscript; available in PMC 2017 November 09. 


\section{Table 2}

Screening of focused library for allylic oxidation

\begin{tabular}{cccc}
\hline Entry & Catalyst $^{\boldsymbol{a}}$ & Active-Site Ala Substitutions & Desired/Undesired $\boldsymbol{b}$ \\
\hline 1 & P450 & - & 0.86 \\
2 & $2 \mathrm{BM} 1$ & L75A, L181A, L437A & 0.37 \\
3 & $4 \mathrm{H} 5$ & L75A, L177A, L181A & 2.1 \\
4 & $8 \mathrm{C} 7$ & L75A, L181A & 2.8 \\
\hline
\end{tabular}

${ }^{a}$ See supporting information for full list of mutations.

${ }^{b}$ Approximated by separating the products on UHPLC-MS and comparing ion count of C-7 oxidation product to all other mono-oxygenation products $(\mathrm{m} / \mathrm{z}=286)$. See supporting information for more details. 